\title{
Fermentation and nitrogen dynamics in Merino sheep given a low-quality-roughage diet
}

\author{
BY J. V. NOLAN AND S. STACHIW \\ Department of Biochemistry and Nutrition, Faculty of Rural Science, University of New \\ England, Armidale, NSW 2351, Australia
}

\section{(Received 9 July 1978 - Accepted I9 September 1978)}

\begin{abstract}
I. Fermentation in the rumen and nitrogen dynamics in the body were studied in mature Merino sheep given a maintenance ration of a low-quality-roughage diet containing mainly chopped wheat straw.

2. Intake of metabolizable energy was $3.49 \mathrm{MJ} / \mathrm{d}$ and of total $\mathrm{N} 6 \cdot 2 \mathrm{~g} / \mathrm{d}$.

3. From measurements of volatile fatty acid (VFA) production rates and stoichiometric principles, it was calculated that $75 \%$ of the digestible organic matter intake was fermented in the rumen, making an estimated $44 \mathrm{~g} / \mathrm{d}$ microbial dry matter available to the animal.

4. The total flux of ammonia through the rumen $\mathrm{NH}_{3}$ pool, estimated by ${ }^{15} \mathrm{NH}_{3}$ dilution methods, was $8.2 \mathrm{~g} \mathrm{~N} / \mathrm{d}$ of which $3.5 \mathrm{~g} \mathrm{~N} / \mathrm{d}$ was irreversibly lost; thus $4.7 \mathrm{~g} \mathrm{~N} / \mathrm{d}$ was recycled, partly within the rumen (approximately $3.8 \mathrm{~g} \mathrm{~N} / \mathrm{d}$ ) and partly via endogenous secretions (approximately $0.9 \mathrm{~g} \mathrm{~N} / \mathrm{d}$ ). The extensive recycling of $\mathrm{NH}_{3}-\mathrm{N}$ within the rumen indicated that turnover of microbial $\mathrm{N}$ was considerable, and the total production of micro-organisms was at least twice the net outflow.

5. The proportion of the $\mathrm{N}$ in rumen bacteria derived from rumen ammonia was $62 \%$ and thus $38 \%$ was derived from other nitrogenous compounds such as peptides and amino acids.

6. The rates of transfer of blood urea into the rumen, estimated from the appearance of ${ }^{14} \mathrm{CO}_{2}$ or ${ }^{15} \mathrm{NH}_{3}$ in the rumen after intravenous single injections of $\left[{ }^{14} \mathrm{C}\right]$ - and $\left[{ }^{15} \mathrm{~N}\right]$ urea, did not differ significantly and the mean transfer was $2 \cdot 3 \mathrm{~g}$ urea-N/d.

7. Estimates of the rate of irreversible loss of urea-C (i.e. urea synthesis in the body) were obtained by analysis of samples of either blood or urine obtained after a single, intravenous injection of [ $\left.{ }^{14} \mathrm{C}\right] \mathrm{urea}$. The two methods gave results that did not differ significantly. The estimated rate of urea synthesis in the body was $5.3 \mathrm{~g} \mathrm{~N} / \mathrm{d}$. Urea excretion rate was relatively low, i.e. $1.2 \mathrm{~g} \mathrm{~N} / \mathrm{d}$, and thus transfer of urea to the digestive tract was approximately $4 . \mathrm{I} \mathrm{g} \mathrm{N} / \mathrm{d}$. Approximately $53 \%$ of the latter was transferred to the rumen, and $47 \%$ to the rest of the digestive tract. These results are discussed in relation to similar studies with sheep given other diets.
\end{abstract}

8. Various aspects of isotope-tracer methods and the errors that could occur in this type of study are discussed.

In ruminants, urea transferred from the blood to the forestomachs and the hind gut is hydrolysed making available ammonia-nitrogen that may either be taken up by microorganisms or re-absorbed and utilized in the body. Utilization of endogenous urea in this way provides a means whereby $\mathrm{N}$ can be conserved and re-synthesized into amino acids. Microbial protein synthesized in the rumen may be absorbed from the small intestine but it is not clear whether microbial protein synthesized from endogenous $\mathrm{N}$ in the hind gut is also available to the animal; however, the general consensus appears to be that, under normal conditions, absorption of amino acids from the large intestine is probably negligible (Judson et al. 1975; Ulyatt et al. 1975; Elliot \& Little, 1977).

In previous studies of urea and ammonia kinetics in sheep (Cocimano \& Leng, 1967; Nolan \& Leng, 1972; Nolan et al. 1976), quantitative estimates of urea transfer to the forestomachs and the lower digestive tract were made. The results obtained with sheep given a diet of lucerne (Medicago sativa) chaff also provided the basis for development of multicompartmental models of $\mathrm{N}$ metabolism in sheep given medium-quality diets (Nolan, 1975; Mazanov \& Nolan, 1976; Nolan \& Rowe, 1976; Baldwin et al. 1977). The present study was undertaken to extend the available information to cover Merino sheep given restricted amounts of a low-quality-roughage diet. It seemed likely that, under these conditions of dietary stress, $\mathrm{N}$ conservation mechanisms might be more apparent. 
In this study both $\left[{ }^{14} \mathrm{C}\right]$ - and $\left[{ }^{15} \mathrm{~N}\right]$ urea are used for estimating the urea kinetics in the body and the rate of urea transfer to the rumen and lower digestive tract; the results also provide information on fermentation processes in the rumen and absorption of $\mathrm{NH}_{3}$ from the rumen.

\section{MATERIALS AND METHODS}

\section{Experimental animals and diet}

Five Merino ewes (aged 4 years) designated A, B, C, D and E were used. The animals, which were fitted with rumen cannulas, were held in individual metabolism crates in a room that was continually illuminated during the experiments, and during an adaptation and training period of 3 months before the experiments. The ration offered consisted of $(\mathrm{g} / \mathrm{d})$ : 500 wheaten chaff, 50 chaffed lucerne hay, 50 dried molasses. Drinking-water was continuously available. During the pre-experimental period the mean live weights of the animals decreased initially from approximately $36 \mathrm{~kg}$ but stabilized at $33 \pm 0.9$ (SE) $\mathrm{kg}$.

\section{Experimental procedure}

Isotope tracers were injected in three separate experiments. During Expt $\mathrm{r}$, a single intravenous injection of $\left[{ }^{14} \mathrm{C}\right]$ - and $\left[{ }^{15} \mathrm{~N}\right]$ urea was made into each animal. After I week, in Expt 2, a single intraruminal injection of a mixture of $\left({ }^{15} \mathrm{NH}_{4}\right)_{2} \mathrm{SO}_{4}, \mathrm{NaH}^{14} \mathrm{CO}_{3}$ and ${ }^{51} \mathrm{Cr}-$ EDTA was made. A $10 \mathrm{~d}$ digestibility trial was run starting the day before Expt 1 . Approximately I month later, in Expt 3, the estimates of the rates of production of volatile fatty acids (VFA) in the rumen and methane in the rumen and hind gut were made. Between Expts 2 and 3, sheep B did not always eat all its ration and this animal was replaced before Expt 3 by another similar animal (sheep E) which had been maintained under the same experimental conditions. Another digestibility trial was run over $\mathrm{lod}$ commencing I d before Expt 3.

During each digestibility trial, samples of food offered and food refused (small quantities occasionally remained uneaten) were obtained daily. A proportion of the daily output of faeces was dried for $48 \mathrm{~h}$ at $70^{\circ}$ and stored. Urine was collected as it was voided using a method described by Raabe (1968) and drawn by suction into a vessel containing $20 \mathrm{ml}$ glacial acetic acid to which mercuric chloride had been added ( $\mathrm{g} / \mathrm{l}$ ).

Expt $\mathrm{I}$. Intravenous injections of tracers. Animals were prepared with catheters in both jugular veins on the day before injection of tracers. $\left[{ }^{14} \mathrm{C}\right] \mathrm{urea}(60 \mu \mathrm{Ci} ; 50 \mathrm{mg})$ and $\left[{ }^{15} \mathrm{~N}\right] \mathrm{urea}$ $(0.29 \mathrm{Immol} \mathrm{N} ; 96$ atoms \% excess) were dissolved in $\mathrm{I} 0 \mathrm{ml}$ sterile saline $(9 \mathrm{~g}$ sodium chloride/1) and injected via one catheter over a period of approximately $0.5 \mathrm{~min}$; blood samples were then taken into heparinized syringes from the opposite jugular vein catheter at intervals throughout the next $30 \mathrm{~h}$ and urine was collected quantitatively for the next $48 \mathrm{~h}$.

Expt 2. Intraruminal injections of tracers. $\left({ }^{15} \mathrm{NH}_{4}\right)_{2} \mathrm{SO}_{4}(\mathrm{I} \cdot 27 \mathrm{mmol} \mathrm{N} ; 96$ atoms \% excess) and ${ }^{51} \mathrm{Cr}$-EDTA (100 $\mu \mathrm{Ci}$ ) were injected through the rumen cannula in $35 \mathrm{ml}$ water; several minutes later, $\mathrm{NaH}^{15} \mathrm{CO}_{3}(34.3 \mu \mathrm{Ci} ; 50 \mathrm{mg})$ was injected in $50 \mathrm{ml}$ water. Efforts were made to disperse the tracers throughout the rumen contents by directing the solutions to different parts of the rumen using a piece of stiff-plastic tubing. Samples of rumen fluid (10 $\mathrm{ml}$ ) were taken into $0.2 \mathrm{ml} 18 \mathrm{M}$-sulphuric acid at intervals during the next $27 \mathrm{~h}$.

Expt 3. Intraruminal infusion of tracers. VFA production rates were estimated by means of tracer-dilution methods and a continuous infusion of $\left[\mathrm{U}-{ }^{14} \mathrm{C}\right]$ acetate $(0.5 \mu \mathrm{Ci} / \mathrm{ml} ; \mathrm{I} \mu \mathrm{M} / \mathrm{ml}$; $1 \cdot 2 \mathrm{ml} / \mathrm{min}$ ) (see Weller et al. 1967). The rates of methane production in the rumen and hind gut were estimated by tracer-dilution techniques using a continuous infusion of $\left[{ }^{3} \mathrm{H}\right]$ methane ( $\mu \mathrm{Ci} / \mathrm{ml} ; \mathrm{I} \cdot 2 \mathrm{ml} / \mathrm{min}$ ) and the procedures developed by Murray et al. (I 976). Methane lost in flatus was not measured. 


\section{Chemical methods}

The specific radioactivity (SR) of blood and rumen $\mathrm{CO}_{2}-\mathrm{C}$ was determined by the technique of Leng \& Leonard (1965) and of urea-C by the method of Nolan \& Leng (1972). The concentrations of urea in blood and urine were determined using an autoanalyser (Marsh et al. 1957). Urea in the blood and urine, and $\mathrm{NH}_{3}$ in rumen fluid were converted to $\left(\mathrm{NH}_{4}\right)_{2} \mathrm{SO}_{4}$ and enrichment with ${ }^{15} \mathrm{~N}$ was estimated by mass spectrometry using the procedures and precautions described by Nolan \& Leng (1974).

During Expt I difficulties were experienced in obtaining a pure sample of urea- $\mathrm{N}$ from the blood. Recovery of $\mathrm{NH}_{3}-\mathrm{N}$ by distillation of the protein-free blood plasma filtrate, after addition of urease, $\left(E C_{3} .5 . \mathrm{I} .5\right)$ yielded more $\mathrm{N}$ than that present in urea in the blood as determined by the diacetyl monoxime colorimetric method which is highly specific for urea (see Marsh et al. 1957). Thus some $20-30 \%$ of non-urea-N was also obtained. Since only small samples were available, there was insufficient plasma for further analysis. Specific samples of urea- $\mathrm{N}$ were however, more readily obtainable from urine and urea- $\mathrm{N}$ enrichments were obtained by analysis of samples collected during the period after $\left[{ }^{15} \mathrm{~N}\right] \mathrm{urea}$ injection. Before urea- $\mathrm{N}$ could be released using urease, it was necessary to remove the urine preservative, $\mathrm{HgCl}_{2}$, by precipitation with hydrogen sulphide.

Total VFA in rumen fluid was estimated by steam distillation (Annison, I954) and the proportions of individual VFA by gas-liquid chromatography (Erwin et al. 196I). The radioactivity in total VFA was obtained by the methods described by T. J. Kempton \& R. A. Leng (1979, unpublished results).

The total $\mathrm{N}$ and energy contents of food, faeces and urine were determined by standard procedures (Association of Official Agricultural Chemists, 1975).

\section{Calculations}

The rate of irreversible loss of urea-C and urea- $N$. The rate of irreversible loss of urea-C from the body was calculated from results of the $\left[{ }^{14} \mathrm{C}\right]$ urea injection experiments by two methods: (I) using the areas (from 0-I600 min) under the curves fitted to the estimates of plasma urea SR $v$. time (see White et al. 1969), and (2) by an alternative procedure using the fraction of the injected $\left[{ }^{14} \mathrm{C}\right]$ urea dose recovered in urinary urea, and the rate of urinary urea excretion (Ford \& Milligan, 1970), i.e.

rate of irreversible loss of urea- $\mathrm{C}=\frac{\text { rate of urinary urea- } \mathrm{C} \text { excretion }}{\text { proportion of }\left[{ }^{14} \mathrm{C}\right] \text { urea dose recovered in urinary urea }}$.

For reasons described previously, satisfactory estimates of plasma urea- $\mathrm{N}$ enrichment were not obtained following injection of $\left[{ }^{15} \mathrm{~N}\right]$ urea, and therefore the rate of irreversible loss of urea- $\mathrm{N}$ and also the area under the urinary urea enrichment $v$. time curves were calculated only by using the latter procedure.

Urea degradation in the gut. The rate of urea degradation throughout the digestive tract was obtained from the difference between the rate of irreversible loss of urea-C and the rate of excretion of urea in the urine (Cocimano \& Leng, 1967). The rate of urea degradation in the rumen was determined from the appearance of ${ }^{14} \mathrm{CO}_{2}$ or ${ }^{15} \mathrm{NH}_{3}$ resulting from degradation of labelled urea transferred from the blood urea pool. The proportions of $\mathrm{C}$ and $\mathrm{N}$ in the secondary compartments (i.e. rumen $\mathrm{CO}_{2}$ and rumen $\mathrm{NH}_{3}$ ) derived from the primary compartment (blood urea) were given by values for secondary: primary curve areas determined over the period o-1600 min (see Nolan et al. 1976). The rate of degradation in the post-ruminal parts of the digestive tract was then obtained by difference.

Rumen fermentation and fluid dynamics. Rumen volume and rate of flow of water from the rumen were determined from the decrease in radioactivity in rumen fluid with the period 
of time after injection of ${ }^{51} \mathrm{Cr}$-EDTA (Downes \& McDonald, 1964). The ${ }^{51} \mathrm{Cr}$-EDTA which was injected in the same solution as the ${ }^{15} \mathrm{NH}_{3}$ was used as a means of correcting for noninstantaneous mixing of ${ }^{15} \mathrm{NH}_{3}$ throughout the rumen contents (see Nolan \& Leng, 1974). To allow for the effects of mixing of tracers, ${ }^{15} \mathrm{NH}_{3}$-enrichment values for the period during which ${ }^{51} \mathrm{Cr}$-EDTA was equilibrating were ignored; the $\mathrm{NH}_{3}$-enrichment curve was fitted through the later enrichment values and was constrained to have a value at the time of injection corresponding to the dilution of ${ }^{15} \mathrm{NH}_{3}$ in an $\mathrm{NH}_{3}$ compartment with a mass defined by the product of rumen $\mathrm{NH}_{3}$ concentration and rumen volume. The rates of total fiux, irreversible loss and recycling of rumen ammonia $\mathrm{NH}_{3}-\mathrm{N}$ were calculated using the enrichment $v$. time curves for rumen $\mathrm{NH}_{3}$ (Nolan \& Leng, 1974). The proportion of rumen bacterial $\mathrm{N}$ derived from rumen $\mathrm{NH}_{3}$ during the experiment was given by the secondary: primary curve area for the period o-I 600 min after injection of $\left({ }^{15} \mathrm{NH}_{4}\right)_{2} \mathrm{SO}_{4}$.

Measurements of the size of the bicarbonate compartment, and the rates of total flux and irreversible loss of rumen bicarbonate were obtained by similar procedures except that it was not possible to allow for non-instantaneous mixing.

The rates of production of VFA were calculated by the methods of Weller et al. (I967) and of methane in the rumen and hind gut by the method of Murray et al. (1976).

Models of $N$ and $C$ flows. The results from the ${ }^{15} \mathrm{~N}$ and ${ }^{14} \mathrm{C}$ tracer experiments were used to define, for each animal, a general two-compartment model of $\mathrm{N}$ flows into and out of plasma urea and rumen $\mathrm{NH}_{3}$ and also a similar model for $\mathrm{C}$ flows into and out of blood $\mathrm{CO}_{2}$ and rumen $\mathrm{CO}_{2}$. The procedures used have been described by Nolan et al. (1976). In order to obtain a solution to the $\mathrm{C}$ model a value for the proportion of blood urea-C derived from rumen $\mathrm{CO}_{2}$ was needed and a value $(35 \%)$ obtained in a comparable experiment (J. V. Nolan, unpublished results) was used.

\section{RESULTS}

\section{$N$ and energy status of the sheep}

Throughout the experimental periods, the sheep consumed approximately $95 \%$ of the ration offered. The resulting mean intake of $465 \mathrm{~g}$ organic matter (OM)/d provided a total energy intake of $8.67 \mathrm{MJ} / \mathrm{d}$ and $6 \cdot 2 \mathrm{~g} \mathrm{~N} / \mathrm{d}$. The apparent digestibility of $\mathrm{N}$, and also excretion of total $\mathrm{N}$ in urine, measured during Expt $\mathrm{I}$ are given in Table I. On average, $\mathrm{N}$ retention was slightly positive (see Table I). The estimates of apparent digestibility of the dietary OM from both collection periods were similar, i.e. 0.52 and 0.50 , respectively.

Estimates of the rates of production of acetic, propionic and butyric acids in the rumen are given in Table 2, together with estimates of the rates of production of methane in the rumen and in the hind gut. The mean metabolizable energy (ME) intake, calculated from digestible energy using these estimates of methane production and urinary energy loss was $3 \cdot 49 \mathrm{MJ} / \mathrm{d}$.

\section{$\mathrm{NH}_{3}$ kinetics and water turnover in the rumen}

The changes with time interval after injection in radioactivity of ${ }^{51} \mathrm{Cr}$-EDTA and of concentration and enrichment of $\mathrm{NH}_{3}-\mathrm{N}$ in the rumen fluid and enrichment of rumen bacterial $\mathrm{N}$ and plasma urea- $\mathrm{N}$ after injection of a mixture of ${ }^{51} \mathrm{Cr}$-EDTA and $\left({ }^{15} \mathrm{NH}_{4}\right)_{2} \mathrm{SO}_{4}$ are given in Fig. I. The nature of the decrease in ${ }^{51} \mathrm{Cr}$-EDTA concentration in rumen fluid, which was adequately described by a single exponential function, indicates that both tracers $\left({ }^{15} \mathrm{~N}\right.$ and ${ }^{51} \mathrm{Cr}$ ) were quickly dispersed throughout the rumen fluid (in all animals within $\mathrm{I} h$ ) and that water turnover was constant throughout the experimental period. In contrast the enrichment in rumen $\mathrm{NH}_{3}-\mathrm{N}$ with time after the intraruminal injection of ${ }^{15} \mathrm{NH}_{3}$ was best described by a curve with two exponential functions (Fig. I). Estimates of water and $\mathrm{NH}_{3}$ flows out of the rumen based on calculations made from the ${ }^{51} \mathrm{Cr}$-EDTA results are 
Table I. Nitrogen intake, apparent $N$ digestibility, $N$ excretion, $N$ balance and live weights of sheep consuming a low-quality-roughage diet*

$\begin{array}{lccccc}\text { Sheep } & \text { Live wt (kg) } & \begin{array}{c}\text { Apparent N } \\ \text { digestibility }\end{array} & \begin{array}{c}\text { Urinary N ex- } \\ \text { cretion }(\mathrm{g} \mathrm{N} / \mathrm{d})\end{array} & \begin{array}{c}\mathrm{N} \text { balance } \\ (\mathrm{g} \mathrm{N} / \mathrm{d})\end{array} & \begin{array}{c}\text { Urine flow- } \\ \text { rate }(1 / \mathrm{d})\end{array} \\ \mathrm{A} & 35.0 & 0.5 \mathrm{I} & 2.5 & +0.3 & 0.29 \\ \mathrm{~B} & 33.6 & 0.49 & 2.5 & +0.6 & 0.4 \mathrm{I} \\ \mathrm{C} & 3 \mathrm{I} \cdot 8 & 0.48 & 2.8 & -0.1 & 0.38 \\ \mathrm{D} & 3 \mathrm{I} \cdot \mathrm{I} & 0.46 & 2 . \mathrm{I} & +0.7 & 0.30 \\ \text { Mean } & 32.9 & 0.49 & 2.5 & +0.4 & 0.35 \\ \mathrm{SE} & 0.9 & 1.0 & 0.14 & 0.18 & 0.030\end{array}$

* For details, see p. 64 .

Table 2. Expt 2. Rumen volatile fatty acid production rates $(\mathrm{mol} / \mathrm{d})$ and rates of production of methane in the rumen $(\mathrm{mol} / \mathrm{d})$ and the hind gut (mmol/d) of sheep consuming a low-qualityroughage diet $(465 \mathrm{~g} O M / d)^{*}$

\begin{tabular}{|c|c|c|c|c|c|}
\hline \multirow[b]{2}{*}{ Sheep } & \multicolumn{4}{|c|}{ Rumen } & \multirow[b]{2}{*}{ Hind gut methane } \\
\hline & Acetate & Propionate & Butyrate & Methane & \\
\hline A & $I \cdot 7 I$ & 0.40 & 0.20 & 0.48 & 22 \\
\hline C & $I \cdot 3 I$ & 0.34 & 0.14 & 0.74 & 93 \\
\hline $\mathrm{D}$ & $I \cdot 31$ & 0.32 & 0.13 & 0.69 & 66 \\
\hline $\mathrm{E}$ & $I \cdot 66$ & 0.39 & 0.14 & 0.84 & 17 \\
\hline Mean & $I \cdot 50$ & $0 \cdot 36$ & 0.15 & 0.69 & 50 \\
\hline SE & $0 . I I$ & 0.019 & 0.016 & 0.076 & 18 \\
\hline
\end{tabular}

* For details, see p. 64.

given in Table 3. The rates of total flux and irreversible loss of $\mathrm{NH}_{3}$ from the rumen $\mathrm{NH}_{3}$ pool and the proportion of rumen bacterial $\mathrm{N}$ derived from rumen $\mathrm{NH}_{3}$ during the sampling period, calculated from the $\mathrm{N}$ enrichment values given in Fig. I, are given in Table 4 (see Nolan \& Leng, 1974).

\section{Rumen bicarbonate kinetics}

The compartment size and the rate of irreversible loss of rumen fluid bicarbonate, calculated from the results in Fig. 2, are given in Table 4.

\section{Urea kinetics in the body}

There was a decrease in SR of urea-C after intravenous $\left[{ }^{14} \mathrm{C}\right]$ urea injection into the blood, and an appearance of $\mathrm{H}^{14} \mathrm{CO}_{3}$ in the rumen (see Fig. 3). The change in SR of plasma urea-C with time interval after injection was well described by a curve with two exponential functions, the first having its main effect during the first $20 \mathrm{~min}$ after the injection and the second in the interval $20-1600 \mathrm{~min}$. This curve indicates that $\left[{ }^{14} \mathrm{C}\right]$ urea was distributed at first through a small compartment and then subsequently through a larger compartment and that recycling of ${ }^{14} \mathrm{C}$ from degraded urea was negligible. Estimates of urea compartment size and the rate of irreversible loss of urea calculated using these plasma urea-C SR values, are given in Table 5, along with estimates of plasma urea concentrations and the rates of urea excretion in the urine and urea degradation in the digestive tract.

Enriched $\mathrm{NH}_{3}-\mathrm{N}$ also entered the rumen after injection of $\left[{ }^{15} \mathrm{~N}\right]$ urea (see Fig. 3). Experimental values for the enrichment of plasma urea- $\mathrm{N}$ corrected for non-urea- $\mathrm{N}$ additions, assuming that this non-specific $\mathrm{N}$ was unenriched, are also given in Fig. 3, but these were not used in any of the calculations (see p. 65). Plasma urea and rumen $\mathrm{NH}_{3}$ concentrations were reasonably constant through Expt I and are also given in Fig. 3. 

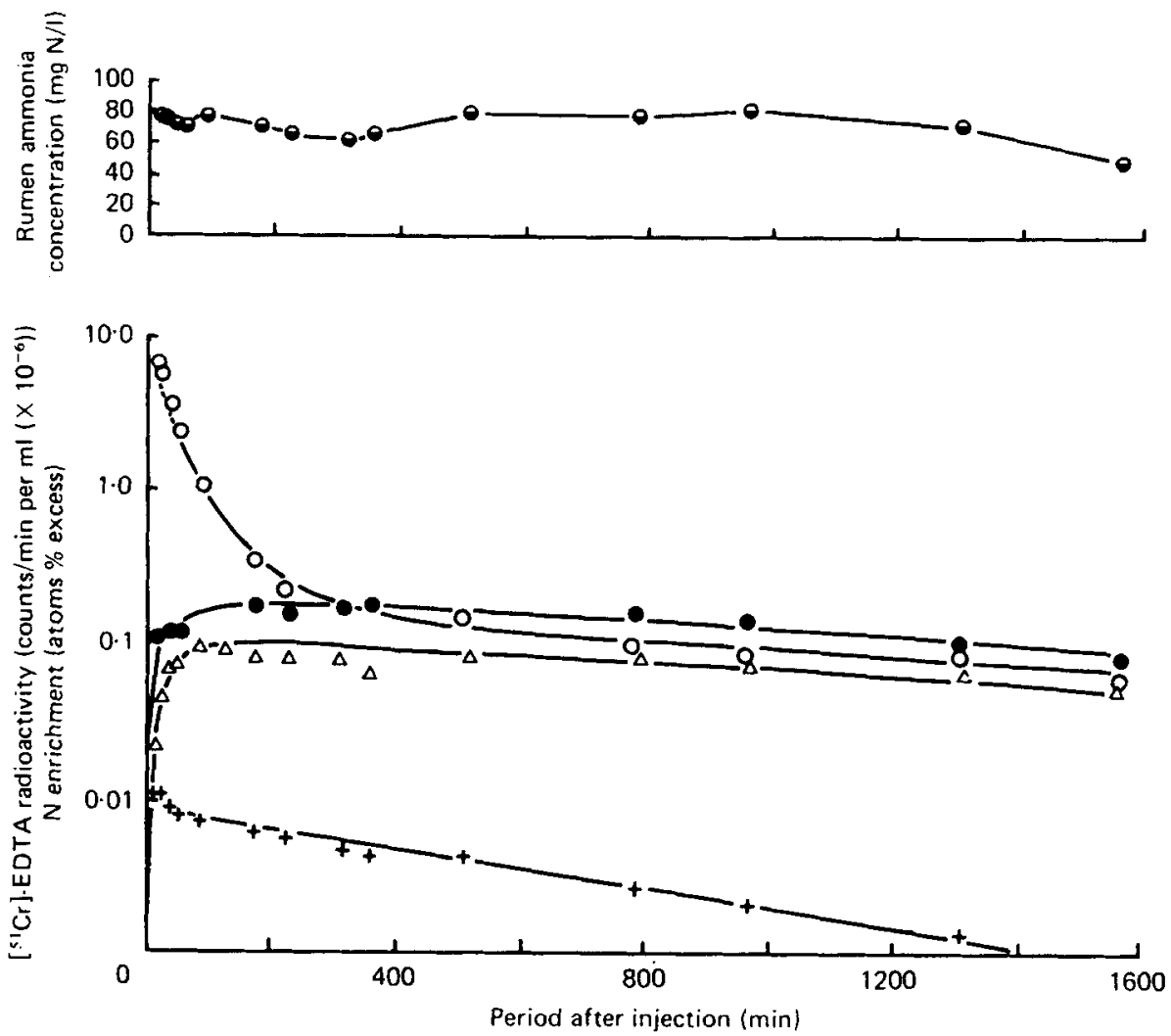

Fig. I. Enrichments (atoms \% excess) of rumen ammonia-N $(O)$, rumen bacterial $\mathrm{N}(\bullet)$ and plasma urea- $\mathrm{N}(\triangle)$, and the radioactivity (counts/min per $\mathrm{ml}\left(\times \mathrm{IO}^{-8}\right)$ ) of $\left.{ }^{51} \mathrm{Cr}\right]$-EDTA (atoms $\%$ excess) in rumen fluid $(+)$ after a single injection of a solution containing $\left({ }^{15} \mathrm{NH}_{4}\right)_{2} \mathrm{SO}_{4}(1 \cdot 22 \mathrm{mmol}$ $\left.{ }^{15} \mathrm{~N}\right)$ and $\left[{ }^{51} \mathrm{Cr}\right]-\mathrm{EDTA}(100 \mu \mathrm{Ci})$ into the rumen of a sheep (sheep D) given a low-quality-roughage diet (for details, see p. 64). Rumen $\mathrm{NH}_{3}$ concentrations (mg N/l) $(\ominus$ ) during the sampling period are also given.

Table 3. Expt 2. Water and ammonia flows from the rumen of sheep given a low-qualityroughage diet*

\begin{tabular}{|c|c|c|c|c|c|c|}
\hline \multirow[b]{2}{*}{ Sheep } & \multicolumn{3}{|c|}{ Water } & \multicolumn{3}{|c|}{$\mathrm{NH}_{3}$} \\
\hline & $\underset{\text { (I) }}{\text { Volume }} \dagger$ & $\begin{array}{l}\text { Efflux } \dagger \\
(1 / d)\end{array}$ & $\begin{array}{l}\text { Mean } \\
\text { retention } \\
\text { time } \dagger \\
\text { (d) }\end{array}$ & $\begin{array}{c}\text { Concentration } \\
(\mathrm{mg} \mathrm{N} / \mathrm{l})\end{array}$ & $\begin{array}{c}\text { Pool } \\
\text { size } \\
(\mathrm{mg} \mathrm{N})\end{array}$ & $\begin{array}{c}\text { Efflux } \\
\text { in water } \\
(\mathrm{mg} \mathrm{N} / \mathrm{d}\end{array}$ \\
\hline A & $2 \cdot 9$ & $5 \cdot 3$ & 0.53 & $58 \quad(0.27) \S$ & I69 & 310 \\
\hline B & $3 \cdot 4$ & 6.9 & 0.50 & $57 \quad(0.29)$ & 195 & 393 \\
\hline C & $3 \cdot 4$ & $5 \cdot 3$ & 0.63 & $67 \quad(0.14)$ & 227 & 355 \\
\hline D & 3.7 & $8 \cdot 5$ & 0.43 & $69 \quad(0 \cdot 19)$ & 256 & 587 \\
\hline Mean & 3.4 & 6.5 & 0.52 & 63 & 212 & $4 \mathrm{II}$ \\
\hline SE & 0.17 & 0.77 & 0.042 & $3 \cdot I$ & 19 & $6 \mathrm{I}$ \\
\hline
\end{tabular}

* For details, see p. 64.

$\uparrow$ Calculated from ${ }^{51} \mathrm{Cr}$-EDTA kinetics.

$\ddagger$ Calculated as the product of rumen volume (l) and rumen $\mathrm{NH}_{3}$ concentration (mg N/l).

$\S$ Coefficients of variation for fifteen samples taken in Expt. 2. 
Table 4. Expt $\mathrm{x}$. Kinetics of carbon dioxide and ammonia in the rumen and the percentage of their carbon and nitrogen derived from degraded plasma urea

\begin{tabular}{|c|c|c|c|c|c|c|c|}
\hline \multirow[b]{2}{*}{ Sheep } & \multicolumn{3}{|c|}{ Rumen bicarbonate } & \multicolumn{4}{|c|}{ Rumen $\mathrm{NH}_{3}$} \\
\hline & $\begin{array}{l}\text { Pool } \\
\text { size } \\
\text { (g C) }\end{array}$ & $\begin{array}{c}\text { Irreversible } \\
\text { loss } \\
(\mathrm{g} \mathrm{C} / \mathrm{d})\end{array}$ & $\begin{array}{l}\text { Percentage } \\
\text { of bicarbon- } \\
\text { ate-C from } \\
\text { plasma urea }\end{array}$ & $\begin{array}{l}\text { Total } \\
\text { flux } \\
(\mathrm{g} \mathrm{N} / \mathrm{d})\end{array}$ & $\begin{array}{c}\text { Irreversible } \\
\text { loss } \\
(\mathrm{g} \mathrm{N} / \mathrm{d})\end{array}$ & $\begin{array}{l}\text { Percentage } \\
\text { of } \mathrm{NH}_{3}-\mathrm{N} \\
\text { from plasma } \\
\text { urea }\end{array}$ & $\begin{array}{c}\text { Percentage } \\
\text { of bacterial- } \\
\mathrm{N} \text { from } \\
\mathrm{NH}_{3}\end{array}$ \\
\hline A & $\mathrm{I} \cdot 6$ & 43 & $2 \cdot 0$ & $6 \cdot 4$ & $3 \cdot 1$ & 54 & 68 \\
\hline B & $1 \cdot 2$ & 46 & $2 \cdot 0$ & 9.0 & $4 \cdot 3$ & 62 & 66 \\
\hline $\mathrm{C}$ & $1 \cdot 5$ & 41 & 1.5 & $9 \cdot 2$ & $3 \cdot 6$ & 39 & 64 \\
\hline D & $\mathrm{I} \cdot 6$ & 47 & $2 \cdot 3$ & $8 \cdot 1$ & $2 \cdot 8$ & 64 & $5 \mathrm{I}$ \\
\hline Mean & $I \cdot 5$ & 44 & $2 \cdot 0$ & $8 \cdot 2$ & 3.5 & 55 & 62 \\
\hline $\mathrm{SE}$ & 0.09 & I.4 & 0.17 & 0.6 & 0.33 & $5 \cdot 7$ & 3.8 \\
\hline
\end{tabular}

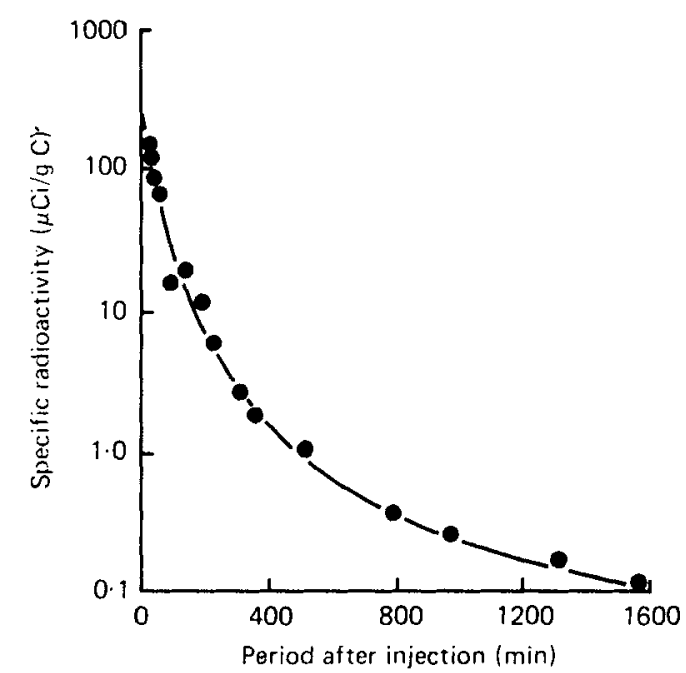

Fig. 2. Specific radioactivity ( $\mu \mathrm{Ci} / \mathrm{g}$ carbon) of rumen bicarbonate- $\mathrm{C}(\bullet)$ after a single injection of $\mathrm{H}^{14} \mathrm{CO}_{3}^{-}(34.3 \mu \mathrm{Ci})$ into the rumen of a sheep (sheep D) given a low-quality-roughage diet (for details, see p. 64).

The values for percentage recovery of the intravenously injected urea tracers are given in Table 6 . The percentage of the ${ }^{15} \mathrm{~N}$ from the $\left[{ }^{15} \mathrm{~N}\right]$ urea recovered in urinary urea during the $2 \mathrm{~d}$ after administration $(32.4 \%)$ was greater than the percentage of the ${ }^{14} \mathrm{C}$ from $\left[{ }^{14} \mathrm{C}\right]$ urea $(23.6 \%)$. The mean rate of irreversible loss of urea-N during this period $(4.7 \mathrm{~g}$ $\mathrm{N} / \mathrm{d}$ ) calculated from $\left[{ }^{15} \mathrm{~N}\right]$ urea recovery in the urine was therefore significantly lower $\left(P<0.05\right.$; one-tail, paired $t$ test) than that calculated in the same way from the $\left[{ }^{14} \mathrm{C}\right]$ urea recovery $(2.4 \mathrm{~g} \mathrm{C} / \mathrm{d}$, equivalent to $5.7 \mathrm{~g} \mathrm{~N} / \mathrm{d}$ ) (see Table 6 ).

The mean rate of irreversible loss of urea, calculated from the $\left[{ }^{14} \mathrm{C}\right]$ urea tracer results and the blood urea SR $v$. time curves (Table 5), was not significantly different (paired $t$ test) from that estimated using the urinary $\left[{ }^{14} \mathrm{C}\right]$ urea recovery procedure (Table 6).

\section{Models of $C$ and $N$ flows in the body}

A general, two-compartment model, based on sets of ${ }^{14} \mathrm{C}$ results for each of four sheep, and describing the $\mathrm{C}$ flows into and out of the blood urea and rumen $\mathrm{CO}_{2}$ compartments 

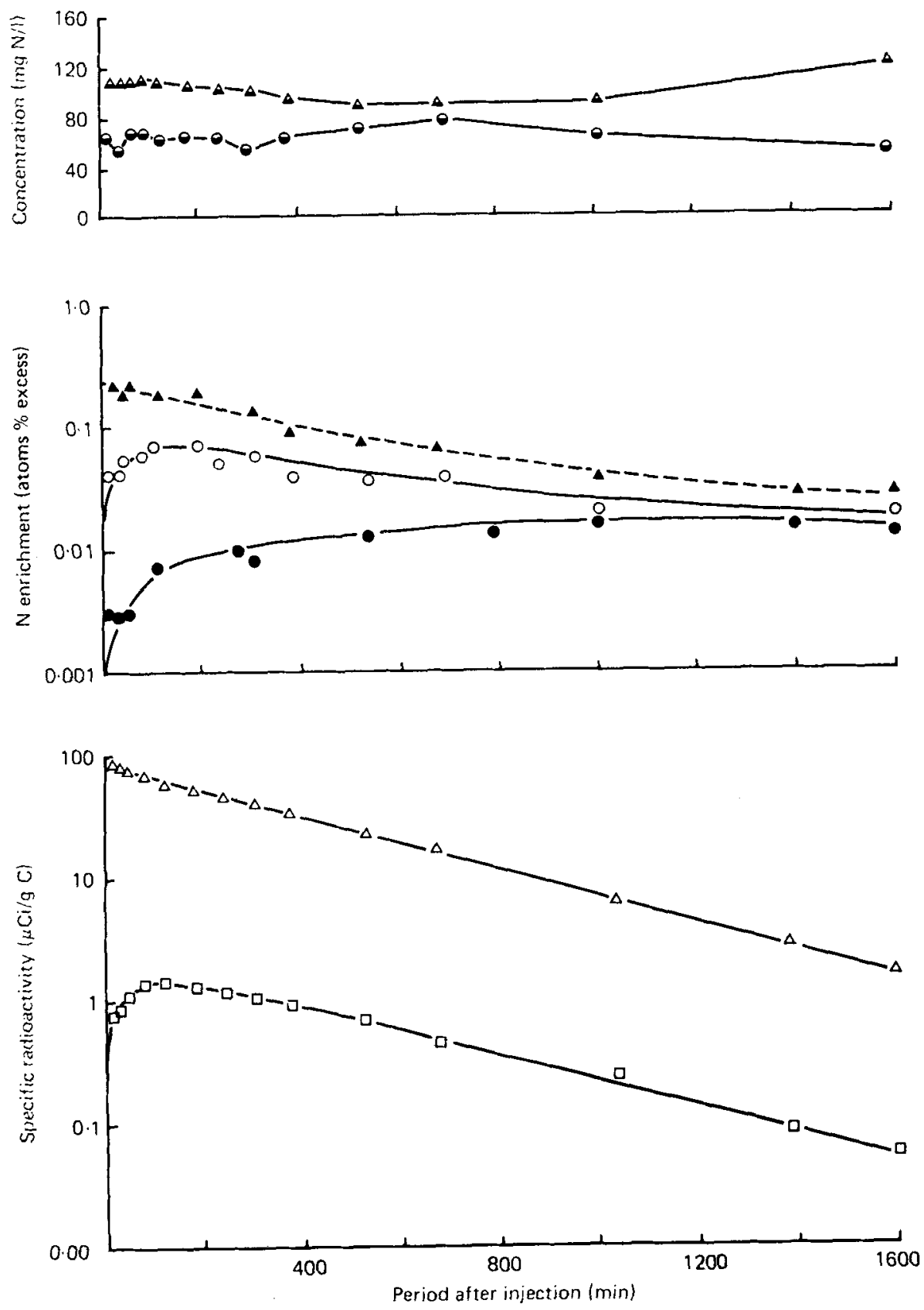

Fig. 3. Enrichments (atoms \% excess) of plasma urea-nitrogen $(\Delta)$, rumen ammonia-N $(O)$ and rumen bacteria $N(\Theta)$ and the specific radioactivity $(\mu \mathrm{Ci} / \mathrm{g}$ carbon) of plasma urea-C $(\triangle)$ and rumen bicarbonate-C $(\square)$ after simultaneous single injections of $\left[{ }^{15} \mathrm{~N}\right]$ urea $\left(0.279 \mathrm{mmol}{ }^{15} \mathrm{~N}\right)$ and $\left[{ }^{14} \mathrm{C}\right]$ urea $(60 \mu \mathrm{Ci})$ into the blood of a sheep (sheep D) given a low-quality-roughage diet. The concentrations $(\mathrm{mg} \mathrm{N} / \mathrm{l})$ of plasma urea $(\Delta)$ and the rumen ammonia $(\theta)$ during the period of sampling are also given. 
Table 5. Plasma urea concentration and the rate of synthesis of urea in the body and its excretion in urine or degradation in the digestive tract in sheep given a low-quality-roughage diet $^{*}$

(The measurements were made by means of a single intravenous injection of $\left[{ }^{14} \mathrm{C}\right]$ urea)

\begin{tabular}{|c|c|c|c|c|c|c|}
\hline Sheep & $\begin{array}{c}\text { Plasma } \\
\text { concentration } \\
\text { (mg N/l) }\end{array}$ & $\begin{array}{l}\text { 'Pool' } \\
\text { size } \dagger \\
(\mathrm{g} \mathrm{N})\end{array}$ & $\begin{array}{l}\text { Space } \\
\text { (\% live- } \\
\text { wt) }\end{array}$ & $\begin{array}{c}\text { Synthesis } \\
\text { rate } \ddagger \\
(\mathrm{g} \mathrm{N} / \mathrm{d})\end{array}$ & $\begin{array}{l}\text { Urinary } \\
\text { excretion } \\
(\mathrm{g} \mathrm{N} / \mathrm{d})\end{array}$ & $\begin{array}{l}\text { Degradation } \\
\text { rate\& } \\
(\mathrm{g} \mathrm{N} / \mathrm{d})\end{array}$ \\
\hline A & $50(0 \cdot 19) \|$ & 0.85 & 50 & $4 \cdot 7$ & $I \cdot I$ & 3.6 \\
\hline B & $59(0.12)$ & I.07 & 53 & 5.5 & $I \cdot 3$ & $4 \cdot 2$ \\
\hline$\overline{\mathrm{C}}$ & $66(0.9)$ & I.06 & 52 & $4 \cdot 7$ & $1 \cdot 5$ & $3 \cdot I$ \\
\hline D & $113(0.15)$ & $I \cdot 75$ & 50 & $6 \cdot 2$ & I. & $5 \cdot 2$ \\
\hline Mean & 72 & I. I 8 & $5 \mathrm{I}$ & $5 \cdot 3$ & $I \cdot 2$ & $4 \cdot 0$ \\
\hline $\mathrm{SE}$ & 14 & 0.20 & 0.75 & 0.36 & 0.11 & 0.45 \\
\hline
\end{tabular}

* For details, see p. 64 .

$\dagger$ Calculated from the intercept value of the second term in a two-exponential fit to the experimental results for urea SR with time interval after $\left[{ }^{14} \mathrm{C}\right]$ urea injection.

$\ddagger$ The rate of irreversible loss of urea-C from the plasma, assuming that re-incorporation of urea-C after urea degradation is negligible.

$\S$ Calculated as urea synthesis rate minus urea excretion rate.

$\|$ Coefficients of variation for fifteen samples taken during the 1600 min after $\left[{ }^{14} \mathrm{C}\right]$ urea injection.

Table 6. Estimates of the rates of irreversible loss of urea- $C$ and urea- $N$ from the body urea pool of sheep given a low-quality-roughage diet*

(The estimates were made using concurrent single injections of $\left[{ }^{14} \mathrm{C}\right]$ and $\left[{ }^{15} \mathrm{~N}\right]$ urea into the blood and subsequent recovery of these tracers in the urine)

Recovery in urine (\% injected dose)

\begin{tabular}{|c|c|c|c|c|c|c|}
\hline \multirow{2}{*}{$\begin{array}{l}\text { Time interval } \\
\text { after } \\
\text { injection }(h) . . . \\
\text { Sheep }\end{array}$} & \multicolumn{2}{|c|}{$\left[{ }^{14} \mathrm{C}\right]$ urea } & \multicolumn{2}{|c|}{$\left[{ }^{15} \mathrm{~N}\right]$ urea } & \multicolumn{2}{|c|}{ Rate of irreversible loss of urea } \\
\hline & 24 & 48 & 24 & 48 & $\begin{array}{c}{ }^{\left[{ }^{14} \mathrm{C}\right] \text { urea }} \\
(\mathrm{g} \mathrm{C} / \mathrm{d})\end{array}$ & $\begin{array}{c}\left.{ }^{15} \mathrm{~N}\right] \text { urea } \\
(\mathrm{g} \mathrm{N} / \mathrm{d})\end{array}$ \\
\hline A & $23 \cdot 6$ & 0.8 & $30 \cdot 6$ & $4 \cdot 4$ & $2 \cdot 0 \quad(4 \cdot 7) \ddagger$ & 3.6 \\
\hline B & $29 \cdot 2$ & 0.4 & $36 \cdot 3$ & $4 \cdot I$ & $I .9 \quad(4 \cdot 5)$ & $3 \cdot 6$ \\
\hline $\mathrm{C}$ & $26 \cdot 2$ & 0.7 & $31 \cdot 0$ & $4 \cdot 0$ & $2.5 \quad(5.7)$ & $4 \cdot 8$ \\
\hline D & 12.8 & - & $15 \cdot 0$ & - & $3.3 \quad(7.8)$ & $6 \cdot 7$ \\
\hline Mean & $23 \cdot 0$ & 0.6 & $28 \cdot 2$ & $4 \cdot 2$ & $2.4 \quad(5 \cdot 7)$ & $4 \cdot 7$ \\
\hline SE & $3 \cdot 6$ & 0.12 & $4 \cdot 6$ & 0.12 & $0.32(0.76)$ & 0.73 \\
\hline
\end{tabular}

* For details, see p. 64.

† Calculated as the rate of urinary urea excretion $(\mathrm{g} \mathrm{N} / 24 \mathrm{~h})$ divided by the fraction of $\left[{ }^{14} \mathrm{C}\right]$ or $\left[{ }^{15} \mathrm{~N}\right]$ urea recovered in the urine in $24 \mathrm{~h}$.

$¥$ Units of $\mathrm{g} \mathrm{N} / \mathrm{d}$ to allow direct comparison with estimates of rate of irreversible loss of urea based on specific radioactivity of plasma urea $\mathrm{C}$, see Table 5.

and movements of $\mathrm{C}$ between them is given in Fig. $4 a$. A similar model of $\mathrm{N}$ flows with respect to blood urea and rumen ammonia is given in Fig. $4 b$.

\section{DISCUSSION}

The daily ration given to the sheep ( $18.5 \mathrm{~g}$ digestible $\mathrm{OM} /$ live weight ${ }^{0.73}$ ) was barely sufficient for maintenance. However, the live weights remained constant for the last two months of the pre-experimental period and during the experiments, having decreased from 36 to $33 \mathrm{~kg}$ when the animals were first changed to the diet. The intakes of ME and apparently digestible crude protein $(\mathrm{N} \times 6 \cdot 25)$ were respectively only 76 and $66 \%$ of the minimum maintenance allowances suggested by the Agricultural Research Council (1965) for non-pregnant, non- 
(a)

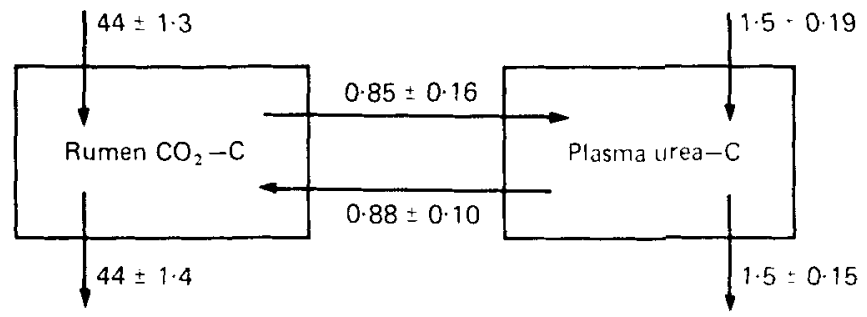

(b)

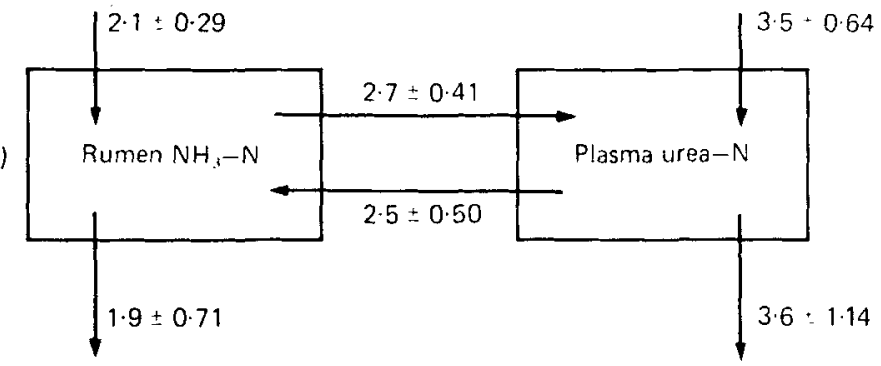

Fig. 4. Two compartment models of (a) urea-carbon and $(b)$ urea-nitrogen movement in sheep given a low-quality-roughage diet (for details, see p. 64). Mean values $( \pm \mathrm{sE})(\mathrm{g} \mathrm{C} / \mathrm{d} ; \mathrm{g} \mathrm{N} / \mathrm{d}$ ) were obtained by averaging results from each of four animals.

lactating sheep of this live weight living indoors, indicating that these Merino sheep made particularly efficient use of the dietary nutrients available to them.

Assuming that the fermentation in the rumen conformed to the stoichiometry of Leng (1973), then I.I mol hexose were required daily to give rise to the measured rate of VFA production. If all the digestible $\mathrm{OM}$ in the ration is considered to be potentially hexose $(\mathrm{I} 62 \mathrm{~g} \mathrm{OM} / \mathrm{mol})$ in the rumen, then approximately $75 \%$ of the OM apparently digested was fermented in the rumen. Assuming the same stoichiometry, the ATP derived during the fermentation would have permitted a net growth of $44 \mathrm{~g}$ (dry) microbial cells, and utilized $4.4 \mathrm{~g} \mathrm{~N} / \mathrm{d}$ (Leng, 1973). The latter value is similar to that obtained using the formula, $\mathrm{RDN}=\mathrm{I} \cdot 25 \mathrm{ME}$, where $\mathrm{RDN}(\mathrm{g} \mathrm{N} / \mathrm{d})$ is the amount of microbial $\mathrm{N}$ flowing out of the rumen, and $\mathrm{ME}$ is in $\mathrm{MJ} / \mathrm{d}$ (see Roy et al. 1977). This estimate of net microbial $\mathrm{N}$ incorporation is used later in deriving a quantitative model of rumen $\mathrm{N}$ transactions in these animals.

The value for methane production $(0.5 \mathrm{~mol} / \mathrm{d})$ predicted from the stoichiometry of Hungate (I966) is lower than that observed $(0.7 \mathrm{~mol} / \mathrm{d})$. The similarly predicted rumen $\mathrm{CO}_{2}$ production during fermentation represents approximately $30 \%$ of the bicarbonate entering the rumen bicarbonate pool; the rest was apparently transferred from the blood (see Fig. $4 \mathrm{a}$ ).

\section{Steady-state in the animals}

A good approximation to the steady-state conditions necessary for the tracer methods used here was obtained, as was indicated by the regular food intake and fairly constant concentrations of urea in the plasma and $\mathrm{NH}_{3}$ in the rumen fluid throughout the experiments (see Figs I and 2). Moreover, the results given in Fig. I indicate that, in general ${ }^{51} \mathrm{Cr}$-EDTA (and therefore, ${ }^{15} \mathrm{NH}_{3}$ ) were mixed well in the rumen fluid within $60 \mathrm{~min}$, and also that the rate of outflow of rumen fluid was constant during the sampling period. The measurements of ${ }^{15} \mathrm{NH}_{3}$ kinetics in the rumen were not therefore confounded by non-steady-state water turnover. Constancy of faecal and urinary outputs during the digestibility trials and the similarities between concentrations of plasma urea and rumen $\mathrm{NH}_{3}$ between the same 
animals in different experiments, add confidence to the necessary assumption that betweenday variations in metabolism were minimal.

The results are based on the isotope-tracer curves from $0-1600 \mathrm{~min}$ after injection of the tracers. Accordingly, the results are mainly applicable to body compartments that have relatively fast turnover. Other compartments, for example muscle protein, act as almost total sinks for ${ }^{15} \mathrm{~N}$ during the relatively short experimental period. Estimated losses from both $\mathrm{NH}_{3}$ and plasma urea compartments include traced $\mathrm{N}$ entering these sinks as well as that leaving the body in urine or faeces (see Fig. 4). In all relatively short-term tracer experiments the rate of irreversible loss of any traced substance from the primary compartment is therefore likely to be somewhat over-estimated (see Nolan, 1975), although this would not have affected to any appreciable extent the interpretations drawn from the present results.

\section{Comparison of methods for estimating rates of irreverisble loss of urea}

Two methods, based on the intravenous injection of $\left[{ }^{14} \mathrm{C}\right]$ urea, were used to estimate the rate of irreversible loss of urea from plasma (i.e. urea synthesis rate, see Nolan \& Leng, 1974). The estimate based on the proportion of the $\left[{ }^{14} \mathrm{C}\right]$ urea dose excreted in the urine (see Ford \& Milligan, 1970) did not differ significantly from that obtained using the area under the plasma urea SR curve (see Cocimano \& Leng, 1967). However, the nature of the calculations with the urinary $\left[{ }^{14} \mathrm{C}\right]$ urea recovery method is such that small analytical errors, or errors due to incomplete collection of urinary urea are magnified in the estimated urea synthesis rate. The error would always be greater when only a small proportion of the urea synthesized in the body is excreted as occurred in the present experiments. For this reason bladder catheterization or an efficient method of urine collection such as the one described by Raabe (I968) and used in this study, is needed in order to obtain complete recovery of urinary urea.

Because there were problems associated with the estimates of enrichment of urea- $N$ in the blood, and because either plasma or urinary samples gave similar estimates of urea synthesis rate with $\left[{ }^{14} \mathrm{C}\right]$ urea, only the urinary urea recovery method was used as a means of analyzing the results of the experiment in which $\left[{ }^{15} \mathrm{~N}\right]$ urea was injected. When plasma samples were analysed by methods used previously to isolate urea- $\mathrm{N}$ from the blood of sheep given diets of lucerne chaff (Nolan \& Leng, 1972), non-urea-N was also obtained in sufficient quantities to give a highly significant errcr in the urea- $\mathrm{N}$ enrichment values. Small quantities of non-urea- $\mathrm{N}$ are probably always obtained when urea- $\mathrm{N}$ is isolated by the procedures suggested by Nolan \& Leng, (I972) but when blood urea concentrations are relatively high (for example, $>200 \mathrm{mg} \mathrm{N} / 1$, as is common in sheep given medium-quality rations), the non-specific $\mathrm{N}$ represents a negligible proportion of the total $\mathrm{N}$ isolated. When blood urea concentrations are relatively low, as in the present experiments $(72 \mathrm{mg} \mathrm{N} / \mathrm{l})$, the higher proportion of non-urea- $\mathrm{N}$ could lead to serious errors in the estimation of the compartment size and rate of irreversible loss of urea. Moreover, in studies in which low plasma urea concentrations occur and urea enrichment values are underestimated, the extent of transfer of blood urea to the rumen (which is a function of the areas under rumen $\mathrm{CO}_{2}-\mathrm{C}$ and plasma or urinary urea-C enrichment curves) could be seriously over-estimated.

\section{Transfer of urea to the digestive tract}

A variety of in vitro and in vivo methods have been used in order to obtain estimates of the extent of endogenous urea movement into the digestive tract of ruminants, e.g. tissue preparations, saline-filled pouches, and urea loading and tracer techniques. The tracer methods have the advantage that they provide the only means of making these measurements in conscious animals that are relatively undisturbed and feeding normally. Estimates of the amount of urea transferred from the blood to the whole digestive tract have been made with 
the use of $\left[{ }^{14} \mathrm{C}\right]$ urea, for example, by Decker et al. (I96I) and Engelhardt \& Nickel (I965) in goats, and by Cocimano \& Leng (I967) in sheep. In general, the estimates of the rates of urea synthesis, excretion and transfer to the whole digestive tract obtained in the present study are in accord with those obtained previously by this technique in sheep given low $\mathrm{N}$ diets (Cocimano \& Leng, I967). A higher percentage of plasma urea- $\mathrm{N}$ was retained by the sheep given the low $\mathrm{N}$ diet in this study $(76 \%$, see Table 6$)$ than by sheep given a higher $\mathrm{N}$ diet $(59 \%$, see Nolan \& Leng, 1972) and these findings are in close agreement with those obtained using ${ }^{15} \mathrm{~N}$ by Boda \& Havassy (1974).

In contrast to studies of urea degradation in the whole digestive tract, there are only a few experiments reported in which intravenously administered $\left[{ }^{14} \mathrm{C}\right)$ urea has been used as a means of estimating the rate. of transfer of urea specifically to the rumen (MacRae et al. 1977; Norton et al. 1978) and none where its use has been checked simultaneously against the use of $\left[{ }^{15} \mathrm{~N}\right]$ urea. It is important to be able to differentiate the amount of urea entering the rumen per se, from the urea degraded in the intestines (Thornton, 1970; Engelhardt \& Hinderer, 1976; Nolan et al. 1976) as only urea transferred to the rumen is re-used for synthesis (by micro-organisms) of essential amino acids that are likely to be absorbed. A knowledge of the amounts of urea entering different parts of the digestive tract is also needed for any discussion of the 'control' of urea movement, since it seems unlikely that any one physiological process would apply to all the different routes of entry to the digestive tract.

In the present study, information on $\mathrm{N}$ transactions between the body and the rumen was obtained either by using $\left[{ }^{15} \mathrm{~N}\right]-$ or $\left[{ }^{14} \mathrm{C}\right]$ urea. A quantitative two-pool model of $\mathrm{N}$ flows was obtained for each animal by solving sets of simultaneous equations obtained using the values from both the intravenous and intraruminal ${ }^{15} \mathrm{~N}$ tracer experiments (see Nolan et al. 1976). Averaging the individual model values gave the model in Fig. $4 b$. It should be stressed that combining results for different days could introduce some error, although these animals were apparently in 'steady-state' as discussed above. A similar procedure was used to obtain a two-pool model based on the results from the ${ }^{14} \mathrm{C}$-labelled tracers (Fig. $4 a$ ). In order to solve the latter model a value for the precentage of blood urea-C derived from rumen bicarbonate was needed and a value $(35 \%)$ obtained in a comparable experiment (J. V. Nolan, unpublished results) was used. To obtain realistic standard errors in the model solutions, this value was assumed to have a coefficient of variation of 0.4 . The sstimated transfer of plasma urea to rumen $\mathrm{NH}_{3}$ was, however, relatively insensitive to variations in this value.

Although the pathways of urea transfer from the blood to the rumen given in Fig. $4 a, b$ are mainly indicative of urea that is transferred directly and degraded, small amounts of urea-C and urea- $\mathrm{N}$ that are recycled to the rumen pools after post-ruminal degradation are also included. Although the direct route would be similarly estimated by either $\left[{ }^{14} \mathrm{C}\right]$ or $\left[{ }^{15} \mathrm{~N}\right]$ urea, different amounts of $\mathrm{C}$ and $\mathrm{N}$ transferred by indirect routes could be expected to result in small differences between the estimated total flows of urea-C and urea-N. Nevertheless, the mean values obtained by either method were not significantly different (Table 5).

The validity of the results obtained with both tracer methods depends on a basic assumption that the ${ }^{15} \mathrm{NH}_{3}$ and ${ }^{14} \mathrm{CO}_{2}$ from labelled urea transferred in the saliva or through the rumen wall are rapidly distributed throughout the rumen, such that samples taken from an indwelling probe are representative of all the rumen contents. Significant errors could occur if the transit of ${ }^{15} \mathrm{NH}_{3}$ between the point of entry to the rumen and the sampling site were prolonged sufficiently for a declining enrichment gradient to be maintained in this region; this could result in preferential utilization of ${ }^{15} \mathrm{NH}_{3}$ by the micro-organisms more distant from the sampling site and also, as suggested by Allen \& Miller (1976), preferential reabsorption of ${ }^{15} \mathrm{NH}_{3}$. That this was not a serious problem in this study is indicated by the rapid labelling of $\mathrm{NH}_{3}$ and $\mathrm{CO}_{2}$ at the sampling site, reaching near-maximum values less 
than 20 min after intravenous tracer injection (see Fig. 3). Also if mixing cycles in the rumen were slow or erratic, marked variability in the tracer dilution curves could occur, particularly in the period after tracer administration while equilibration is occurring. However, ${ }^{51} \mathrm{Cr}-$ EDTA administered into the rumen was rapidly distributed (Fig. I) indicating that the contents were efficiently mixed in these animals. Furthermore, the variability during the early period of ${ }^{15} \mathrm{NH}_{3}$ and ${ }^{14} \mathrm{CO}_{2}$ appearance after intravenous $\left[{ }^{14} \mathrm{C}\right]$ - and $\left[{ }^{15} \mathrm{~N}\right]$ urea administration was no greater than at any other time during the experiments, again suggesting that the contents were homogenous (i.e. well-mixed). In addition, the values for area under the rumen microbial curves: area under the rumen $\mathrm{N}$ enrichment curves were similar, irrespective of whether ${ }^{15} \mathrm{NH}_{3}$ was injected directly into the rumen contents, or entered indirectly from the blood via the saliva or the rumen wall. This suggests that the intravenously administered tracers entering the rumen via the normal routes of transfer from the body were kinetically indistinguishable from those administered to the rumen.

The similarity of the results obtained by either technique also provides reason for confidence in these results. The two techniques involve kinetically different systems since the rates of turnover of $\mathrm{NH}_{3}$ and $\mathrm{CO}_{2}$ in the rumen are quite different, as are the percentages of $\mathrm{N}$ or $\mathrm{C}$ in each derived from endogenous urea $\left(\mathrm{NH}_{3} 55 \%\right.$; $\mathrm{cf}, \mathrm{CO}_{2} \%$ ). Furthermore, there is extensive use of $\mathrm{NH}_{3}$ by micro-organisms whilst their utilization of $\mathrm{CO}_{2}$ is minimal.

In the sheep on the low-quality-roughage diet used in these experiments, the mean estimate of endogenous urea degradation in the rumen, $2.3 \mathrm{~g} \mathrm{~N} / \mathrm{d}$, represented $58 \%$ of urea degradation in all parts of the digestive tract and was an appreciable input in relation to the $\mathrm{NH}_{3}$ available from other sources in the rumen $(6.1 \mathrm{~g} \mathrm{~N} / \mathrm{d} ;$ Fig. 5$)$. In a comparable study, MacRae et al. (1977) used infusions of $\left[{ }^{14} \mathrm{C}\right]$ urea (intravenously) and $\mathrm{H}^{14} \mathrm{CO}_{3}^{-}$(intraruminally) to estimate the amounts of blood urea-C entering the rumen bicarbonate pool in nine Scottish Blackface wethers given low-quality, freeze-stored grasses $\left(45^{\circ} \mathrm{g} \mathrm{OM} / \mathrm{d}\right.$ ). These workers estimated that the rate of transfer of blood urea to the rumen was between 0.9 and $I \cdot I \mathrm{~g} \mathrm{~N} / \mathrm{d}$. Using the same technique, Norton et al. (I978) estimated that $0.6 \mathrm{~g}$ urea $\mathrm{N} / \mathrm{d}$ entered the rumen of sheep given low-quality, native forages. In both studies the amounts of urea entering could be accounted for by postulating a daily secretion of I0-20 1 saliva with a urea concentration $50-70 \%$ of that present in the blood. Although urea can enter the rumen via the wall (Houpt, 1957; Simonnet et al. 1957), it seems probable that, in sheep given these low-quality-roughage diets, the amounts of urea entering this way were negligible. A similar conclusion was reached by Chalmers et al. (1976) after analysing the results of forty-three of their experiments with sheep (diets were not specified) in which urea concentration was estimated in blood entering and leaving the rumen vascular system. In contrast to these conclusions, however, the entry of urea to the rumen in the present study (Fig. 4) cannot readily be accounted for by salivary secretions alone and there are also numerous suggestions that the total transfer of endogenous urea to the rumen can be much higher than values discussed so far. The values obtained by Kennedy \& Milligan (1978) using ${ }^{15} \mathrm{~N}$ techniques similar to those used in the present study are particularly pertinent. In sheep ( $50-65 \mathrm{~kg})$ given brome grass (Bromus inermis) $(700-1400 \mathrm{~g} \mathrm{OM} / \mathrm{d})$ these workers found that 6-Io g urea-N/d entered the rumen. In a preliminary report of tracer studies with a sheep give a synthetic, $\mathrm{N}$-free basal diet, plus $300 \mathrm{~g}$ sucrose, Potthast et al. (1977) also calculated that $9.5 \mathrm{~g}$ urea-N/d entered the forestomachs. Without the infusion of sucrose, entry of urea was only $2 \cdot 2 \mathrm{~g} \mathrm{~N}^{*} / \mathrm{d}$.

Whether urea transfer is 'controlled' to the animal's advantage is still not clear and the reasons for the differences in various studies between the quantities of endogenous urea entering by passage through the rumen wall and the physiological processes involved are still uncertain. When Houpt (1970) reviewed this topic, the question, which still has not been resolved, was whether passage was by simple diffusion, as suggested by Engelhardt \& 


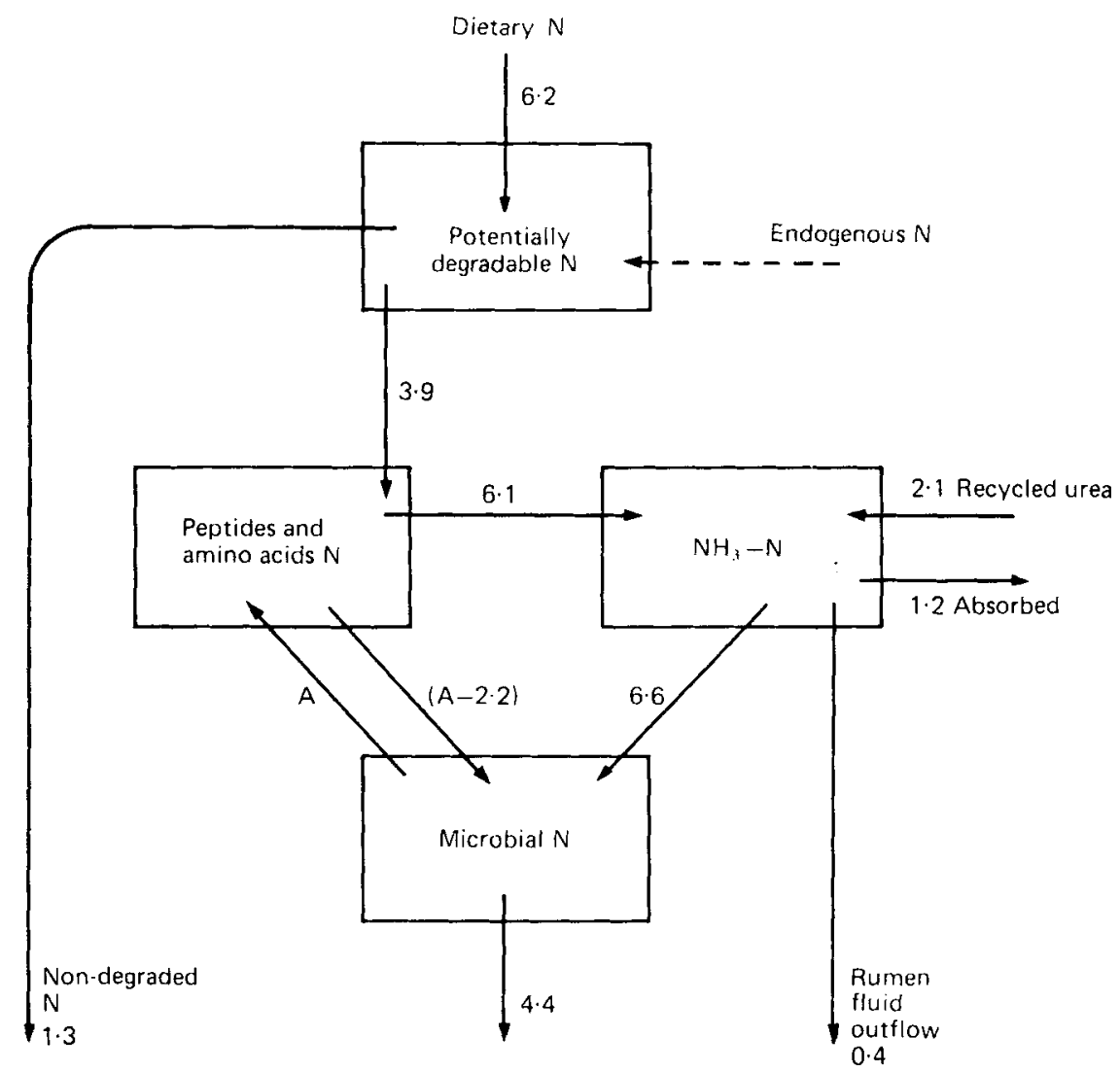

Fig. 5. A model of nitrogen flows in the rumen ( $\mathrm{g} N / \mathrm{d}$ ) of Merino sheep given a low-quality-roughage diet (for details, see p. 64).

Nickel (1965) and Juhász (1965), or by a carrier system, as proposed by Decker et al. (1961) and Gartner (1962). Houpt (1970) presented a 'working' hypothesis in which the cornified layers of the epithelium were considered to be a major barrier to urea movement but a lesser barrier to ammonia. He suggested that the movement of urea into the rumen was facilitated by presence of bacterial urease within the cornified layers where urea degradation resulted in ammonia accumulation. From this region ammonia diffused into the rumen or towards the blood according to the ammonia gradient which was a function of rumen ammonia concentration. Other workers had also suggested that rumen ammonia concentration might be an important controlling factor (Várady et al. 1967; Thornton, 1970) and Kennedy \& Milligan (1978) obtained an inverse relationship between the estimated transfer of urea to the rumen and the corresponding rumen ammonia concentration. However, the relationship does not explain the estimated urea movement in the present study and therefore factors other than rumen ammonia concentration are involved in the modulation of endogenous urea movement into the rumen. Briefly, some of these factors may be as follows.

The quantity of urea entering the temporarily isolated rumen of the cow increased up to threefold when $\mathrm{CO}_{2}$ was bubbled into the rumen contents (Thorlacius et al. 197I) and it also increased when the total VFA or butyric acid concentration was increased in a test solution of unspecified composition in a similar rumen preparation in the liama (Hinderer \& Engelhardt, 1976). These findings imply that urea movement into the rumen may be 
facilitated during periods of increased fermentative activity when $\mathrm{NH}_{3}$ is more likely to limit microbial growth. Dobson et al. (1971) studied the possible connexion between urea entry and blood flow in the rumen vessels but were unable to demonstrate that the two factors were related. Finally it may be worthwhile to re-iterate a fact stressed by Chalmers et al. (1976), i.e. that urea is present in all body fluids. With this in mind, Nolan et al. (1976) postulated that urea would enter the digestive tract wherever fluids are secreted. It follows that any changes in the rate of water movement through the rumen epithelium in response to feeding, changes in osmotic pressure, or hormonal and other influences could also affect the amounts of endogenous urea transferred.

Although many physiological questions concerning urea recycling to the rumen remain unanswered, this topic also needs to be viewed in practical perspective, especially when formulating diets (see, for example, Roy et al. 1977). Recycling of urea is of importance only if ammonia limits fermentation and growth of micro-organisms in the rumen; the amount of endogenous $\mathrm{N}$ recycled then correspondingly reduces the amount of extra dietary $\mathrm{N}$ needed to correct the deficiency. Such a deficiency is most likely to occur when the rumen fermentable dietary $\mathrm{N}$ :rumen fermentable OM ratio is low, as occurs with low quality forages and starch- or sugar-based concentrates. In spite of urea recycling (via saliva and the rumen wall) and in spite of any 'controls' that may exist, microbial growth is, at times, limited by ammonia deficiency (Gillette, 1967 ; Satter \& Slyter, 1974). The relatively low values for recycling obtained in the present study and in the studies of MacRae et al. (1977) and Norton et al. (1978) help to explain why the $\mathrm{N}$ deficiency in the rumen occurs. In pen-feeding situations, this deficiency occurs frequently, and there is an extensive literature (for review, see Helmer \& Bartley, 197I) which demonstrates that responses in feed intake, $\mathrm{N}$ balance and animal growth are obtainable when extra urea is provided in the diet. The fact that dietary urea requirements are normally calculated according to the theoretical $\mathrm{N}$ requirements for rumen micro-organisms, without corrections for recycled $\mathrm{N}$, also suggests that, in practical-feeding terms, the contribution of recycled urea is minimal.

\section{Ammonia kinetics in the rumen}

The rate of total flux of $\mathrm{NH}_{3}$ through the rumen pool $(8 \cdot 2 \mathrm{~g} \mathrm{~N} / \mathrm{d})$ was high relative to the irreversible loss $(3.5 \mathrm{~g} \mathrm{~N} / \mathrm{d})$ indicating that recycling of $\mathrm{N}$, either within, or to and from the rumen in these sheep was considerable $(4 \cdot 7 \mathrm{~g} \mathrm{~N} / \mathrm{d})$. Part of the recycling of rumen ${ }^{15} \mathrm{NH}_{3}-\mathrm{N}$ occurred via pools outside the rumen. The principal route of recycling would have been via plasma urea, and its transfer to the rumen was responsible for re-entry of $23 \%$ of the ${ }^{15} \mathrm{~N}$ originally injected into the rumen (calculated from the measured transfer $(2 \cdot \mathrm{Ig} \mathrm{N} / \mathrm{d}$, Fig. $4 a$ ) and its mean $\mathrm{N}$ enrichment). A small quantity was presumably also recycled external to the rumen in other endogenous inputs, e.g. salivary proteins and sloughed epithelial cells. However, these latter inputs could not have accounted for all of the remaining recycled $\mathrm{N}, 4.7-0.9=3.8 \mathrm{~g} \mathrm{~N} / \mathrm{d}$, most of which must have been recycled within the rumen itself. These results indicate that the total incorporation of $\mathrm{N}$ into microbes may be more than twice the microbial $\mathrm{N}$ outflow from the rumen, suggesting that there was considerable turnover of micro-organisms within the rumen under the conditions of this study (see later, Fig. 5).

An estimate of $\mathrm{NH}_{3}$ absorption from the rumen was obtained by consideration of the flows of ${ }^{15} \mathrm{~N}$ into and out of the rumen. An example of the calculations for one animal (sheep A) is as follows. The inputs of ${ }^{15} \mathrm{NH}_{3}$ to the rumen (total $\mathrm{r} \cdot 50 \mathrm{mmol}{ }^{15} \mathrm{~N}$ ) were made up of the single injection dose ( $1.22 \mathrm{mmol})$ and the ${ }^{15} \mathrm{~N}$ recycled in endogenous materials, principally urea $(0.28 \mathrm{mmol})$, the latter being calculated from a knowledge of the endogenous urea transfer to the rumen (Fig. 4) and its mean ${ }^{15} \mathrm{~N}$ content during the $24 \mathrm{~h}$ after injection (as defined by the mean urinary urea enrichment during this $24 \mathrm{~h}$ ). In a steady-state the 
inputs of ${ }^{15} \mathrm{~N}$ to the rumen must be balanced by the outputs, namely ${ }^{15} \mathrm{~N}$ flowing out of the forestomachs in digesta or being directly absorbed, presumably in the form of $\mathrm{NH}_{3}$. Assuming that the principal losses of ${ }^{15} \mathrm{~N}$ in digesta occurred either in $\mathrm{NH}_{3}$ or in microbial materials, and that the latter had the same $\mathrm{N}$ enrichment as isolated rumen bacteria, the flow of ${ }^{15} \mathrm{~N}$ in both fractions was given by the product of their $\mathrm{N}$ flow-rates and corresponding $\mathrm{N}$ enrichments (total $\left.\mathrm{I} \cdot 28 \mathrm{mmol}^{15} \mathrm{~N}\right)$. If the remaining ${ }^{15} \mathrm{~N}$ loss $(0.22 \mathrm{mmol}$ ) was by absorption of $\mathrm{NH}_{3}-\mathrm{N}$ of known mean enrichment $\left(5.5 \mathrm{Immol}{ }^{15} \mathrm{~N} / \mathrm{mol} \mathrm{N}\right)$, the quantity absorbed was therefore $40 \mathrm{mmol} \mathrm{N} / \mathrm{d}$, i.e. $0.6 \mathrm{~g} \mathrm{~N} / \mathrm{d}$. The mean value for the four sheep calculated individually in the same way was $\mathrm{I} \cdot 2 \pm 0.3 \mathrm{SE} \mathrm{g} \mathrm{N} / \mathrm{d} . \mathrm{NH}_{3}$ absorption of this magnitude is notable in view of the relatively low concentrations of $\mathrm{NH}_{3}$ in the rumen (mean $63 \mathrm{mg} \mathrm{N} / 1$ ).

\section{$A$ rumen model of $N$ flows}

In a similar report of studies of the dynamics of $\mathrm{N}$ metabolism in sheep (Nolan \& Leng, I972), a model of the flows of $\mathrm{N}$ through pools in the rumen of sheep given lucerne chaff was proposed. A comparable model describing the flows of $\mathrm{N}$ through the rumens of the sheep given the low-quality diet in the present study is given in Fig. 5 .

The following information was used to obtain the values given in the model which are mean values for the four sheep in Expt I: (I) dietary $\mathrm{N}$ input $=6.2 \mathrm{~g} \mathrm{~N} / \mathrm{d}$; (2) total flux of rumen ammonia $=8.2 \mathrm{~g} \mathrm{~N} / \mathrm{d}$ (Table 5); (3) recycling of $\mathrm{NH}_{3}-\mathrm{N}$ within the rumen = $3.8 \mathrm{~g} \mathrm{~N} / \mathrm{d}$ (see p. 72); (4) transfer of urea from the blood $=2 . \mathrm{Ig} \mathrm{N} / \mathrm{d}$ (Fig. 4a); (5) the proportion of microbial $\mathrm{N}$ derived from rumen $\mathrm{NH}_{3}=62 \%$ (Table 5); (6) the net outflow of microbial $\mathrm{N}=4.4 \mathrm{~g} \mathrm{~N} / \mathrm{d}$ (see p. 72); (7) the net outflow of $\mathrm{NH}_{3}-\mathrm{N}$ in rumen fluid $=0.4 \mathrm{~g} \mathrm{~N} / \mathrm{d}$ (Table 4 ); and (8) the values not yet defined were obtained on the basis that, in steady-state, inputs equal outputs for each pool.

The estimated total entry of $\mathrm{NH}_{3}$ into the rumen $\mathrm{NH}_{3}$ pool is made up of $2 \cdot \mathrm{I} \mathrm{g} \mathrm{N} / \mathrm{d}$ from blood urea and a further $6.1 \mathrm{~g} \mathrm{~N} / \mathrm{d}$ which must have been derived from the peptide amino acid pool. If the $\mathrm{NH}_{3}$ pool was in steady state, $6.6 \mathrm{~g} \mathrm{~N} / \mathrm{d}$ left the $\mathrm{NH}_{3}$ pool and entered the microbial pool and the net flow from the microbial pool to the peptide-amino acid pool, needed to balance the microbial pool, was therefore $2 \cdot 2 \mathrm{~g} \mathrm{~N} / \mathrm{d}$. With the knowledge of the mean enrichments in the $\mathrm{NH}_{3}$ and microbial pools, it is now theoretically possible to calculate the mean enrichment that occurred in the peptide-amino acid pool, by solving simultaneous equations describing total $\mathrm{N}$ and ${ }^{15} \mathrm{~N}$ balances in the pools, and also to obtain the flows in both directions between the peptide-amino acid pool and the microbial pool. However this calculation indicates that the enrichment in the peptide-amino acid pool was similar to that in the microbial pool, implying that the flow of microbial $\mathrm{N}$ into the peptideamino acid pool was of considerable magnitude in relation to the $3.9 \mathrm{~g} \mathrm{~N} / \mathrm{d}$ of unlabelled $\mathrm{N}$ derived from dietary materials. However, because this pool was not sampled, and the model may be over-simplified, it did not seem advisable to give the values for flow (A) or the reverse flow $(\mathrm{A}-2 \cdot 2 \mathrm{~g} \mathrm{~N} / \mathrm{d})$. Nevertheless a minimum value for the flow of $\mathrm{N}$ from the microbial pool to the peptide-amino acid pool (A) is given by the figure $(3.8 \mathrm{~g} \mathrm{~N} / \mathrm{d})$ for cycling of $\mathrm{NH}_{3}-\mathrm{N}$ within the rumen; the true value of $\mathrm{A}$ would be considerably greater than this.

There are several important points that arise from the model results: (I) the total incorporation of $\mathrm{N}$ into microbial cells in the rumen is almost twice the outflow of microbial $\mathrm{N}$, emphasizing the extensive turnover of microbial $\mathrm{N}$ that occurred in the rumen; (2) $34 \%$ of the microbial $\mathrm{N}$ was derived from nitrogenous compounds more complex than $\mathrm{NH}_{3}$ presumably mainly peptides and amino acids; and (3) the amount of $\mathrm{NH}_{3}$ absorbed was considerable despite quite low concentrations of $\mathrm{NH}_{3}$ in rumen fluid $(63 \mathrm{mg} \mathrm{N} / \mathrm{l})$.

It should be noted that an endogenous non-urea- $\mathrm{N}$ input has not been considered in the calculations, but the principal effect on the model of a quantitatively significant endogenous 
$\mathrm{N}$ input would be to increase the estimated flow from the rumen of non-degraded $\mathrm{N}$ by a similar amount. This is not intended to imply that endogenous non-urea inputs to the rumen are insignificant; indeed, MacRae et al. (1977) suggest that the $\mathrm{N}$ transferred in non-urea forms may exceed that transferred as urea and results from this laboratory support that view (Leng \& Murray, 1972; Nolan, 1975).

Financial support for this work was provided by the Australian Meat Research Committee The Authors would like to thank Professor R. A. Leng, and Drs Hecker, Kempton, Kennedy and Sutherland for helpful criticism of the draft manuscript.

\section{REFERENCES}

Agricultural Research Council (1965). The Nutrient Requirements of Farm Livestock, No. 2, Ruminants. London: Agricultural Research Council.

Allen, S. \& Miller, E. L. (1976). Br. J. Nutr. 36, 353.

Annison, E. F. (1954). Biochem. J. 57, 400.

Association of Official Agricultural Chemists (1975). Official Methods of Analysis, 1 2th ed. Washington, DC: Association of Official Agricultural Chemists.

Baldwin, R. L., Koong, L. J. \& Ulyatt, M. J. (1977). Agric. Systems 2, 255.

Boda, K. \& Havassy, I. (1974). In Tracer Studies on Non-Protein-Nitrogen for Ruminants. II, p. 99. Vienna: Int. Atomic Energy Agency.

Chalmers, M. I., Grant, I. \& White, F. (1976). In Protein Metabolism and Nutrition, p. I59, [D. J. A. Cole, K. N. Boorman, P. J. Buttery, D. Lewis, R. J. Neale and H. Swan, editors]. European Association for Animal Production, No. 16. London: Butterworths.

Cocimano, M. R. \& Leng, R. A. (1967). Br. J. Nutr. 21, 353.

Decker, P., Gartner, K., Hornicke, H. \& Hill, H. (196I). Pflügers Arch. ges. Physiol, 274, 289.

Dobson, A., Sellars, A. F., Thorlacius, S. O. (1971). Am. J. Physiol. 220, I337.

Downes, A. M. \& McDonald, I. W. (I964). Br. J. Nutr. 18, I53.

Elliot, R. \& Little, D. A. (1977). Aust. J. biol. Sci, 30, 203.

Engelhardt, W. v. \& Hinderer, S. (1976). In Tracer Studies on Non-Protein Nitrogen for Ruminants. III, p. 57. Vienna: Int. Atomic Energy Agency.

Engelhardt, W. v. \& Nickel, W. (I965). Pfügers Arch. ges. Physiol. 286, 57.

Erwin, E. S., Marco, G. J. \& Emery, E. M. (1961). J. Dairy Sci. 44, 1768.

Ford, A. L. \& Milligan, L. P. (1970). Can. J. Anim. Sci. 50, I 29.

Gartner, K. (1962). Pflügers Arch. ges. Physiol. 276, 292.

Gillette, D. D. (1967). Am J. Physiol. 213, 271 .

Helmer, L. G. \& Bartley, E. E. (I97I). J. Dairy Sci. 54, 25.

Hinderer, S. \& Engelhardt, W. v. (1976). In Tracer Studies on N'on-Protein Nitrogen for Ruminants. III, p. 59. Vienna: Int. Atomic Energy Agency.

Houpt, T. R. (1957). Physiologist, Wash. I, 43.

Houpt, T .R. (1970). In The Physiology of Digestion and Metabolism in the Ruminant. [A. T. Phillipson, editor]. Newcastle upon Tyne: Oriel Press.

Hungate, R. E. (1966). The Rumen and its Microbes. New York: Academic Press.

Judson, G. J., Abelsamie, R. \& Bird, R. B. (1975). Aust. J. agric. Res, 26, 743.

Juhász, B. (1965). Acta vet. hung. 15, 25.

Kempton, T. J. \& Leng, R. A. (I979). Br. J. Nutr. (In the Press).

Kennedy, P. M. \& Milligan, L. P. (I978). Br. J. Nutr. 40, I 49.

Leng, R. A. (1973). In Chemistry and Biochemistry of Herbage, vol. 3, p. 107 [R. W. Bailey and G. W. Butler, editors]. New York: Academic Press.

Leng, R. A. \& Leonard, G. J. (1965). Br. J. Nutr. 19, 469.

Leng, R. A. \& Murray, R. N. (1972). In Tracer Studies on Non-Protein Nitrogen for Ruminants, I, p. 25 Vienna: Int. Atomic Energy Agency.

MacRae, J. C., Wilson, S., Milne, J. A. \& Spence, M. (1977). Proc. Nutr. Soc. 36, 77 A.

Marsh, W. H., Fingerhut, B. \& Kirsch, E. (1957). Am. J. clin. Path. 28, 681.

Mazanov, A. \& Nolan, J. V. (1976). Br. J. Nutr. 35, 149.

Murray, R. M., Byrant, A. M. \& Leng, R. A. (1976). Br. J. Nutr. 36, I.

Nolan, J. V. (1975). In Digestion and Metabolism in the Ruminant. [I. W. McDonald and A. C. I. Warner, editors]. Armidale, Australia: University of New England Publishing Unit.

Nolan, J. V. \& Leng, R. A. (1972). Br. J. Nutr. 27, 177.

Nolan, J. V. \& Leng, R. A. (1974). Proc. Nutr. Soc. 33, I.

Nolan, J. V., Norton, B. W. \& Leng, R. A. (1976). Br. J. Nutr. 35, I27. 
Nolan, J. V. \& Rowe, J. B. (1976). In Reveiws in Rural Science. II, p. I 51. [T. M. Sutherland, J. R. McWilliam and R. A. Leng, editors]. Armidale, Australia: University of New England Publishing Unit.

Norton, B. W., Murray, R. M., Entwistle, K. W., Nolan, J. V., Ball. F. M. \& Leng, R. A. (1978). Aust. J. agric. Res. 29, 595.

Potthast, V., Prigge, H. \& Pfeffer, E. (1977). Z. Tierphysiol, Tierernahr. Futtermittelkd. 38, 338 (abstract).

Raabe, R. (I968). Lab Pract. 17, 217.

Roy, J. H. B., Balch, C. C., Miller, E. K., Ørskov, E. R. \& Smith, R. H. (1977). Publs. Eur. Ass. Anim. Prod. no. 19.

Satter, L. D. \& Slyter, L. L. (1974). Br. J. Nutr. 32, 199.

Simonnet, H., Le Bars, H., Molle, J. (1957). C. \%. hebd. Seanc. Acad. Sci., Paris, 244, 943.

Thorlacius, S. O., Dobson, A. \& Sellars, A. F. (1971). Am. J. Physiol. 220, I6z.

Thornton, R. F. (1970). Aust. J. agric. Res. 21, 323.

Ulyatt, M. J., Dellow, D. W., Reid, C. S. W. \& Bauchop, T. (1975). In Digestion and Metabolism in the Ruminant [I. W. McDonald and A. C. 1. Warner, editors]. Armidale, Australia: University of New England Publishing Unit.

Várady, J., Boda, K., Havassy, I., Bajo, M. \& Tomas, J. (1967). Physiol. bohemoslav, x6, 57t.

Weller, R. A., Gray, F. V., Pilgrim, A. F. \& Jones, G. B. (1967). Aust. J. agric. Res, 18, 107.

White, R. G., Steel, J. W., Leng, R. A. \& Luick, J. R. (1969). Biochem. J. Ir4, 203. 